\title{
PRIORITIES AND THE DISCHARGE OF CAVEATS (NO. 2): WHITE RESOURCE MANAGEMENT LTD. V. DURISH
}

\section{W.H. HURLBURT \\ I. INTRODUCTION}

The decision of the Court of Appeal in White Resource Management Lid. v. Durish' has cast doubt on some fundamental propositions of land registration in Alberta. The judgment:

- raises doubts whether section 195 of the Land Titles Act ${ }^{2}$ protects a purchaser of a caveated interest against constructive and actual notice of off-register interests.

- holds that an interest continues to exist and to be enforceable after a caveat protecting it has lapsed, but that the courts will treat an attempt at enforcement as abuse of process unless the caveator had a good reason for allowing the caveat to lapse.

- raises doubts that an assignee of an interest is entitled to the priority established by the assignor's caveat.

- suggests that section 62 of the Land Titles Act makes a transferee of land liable to perform the obligations of the transferor under an off-register mineral lease previously granted by the transferor.

\section{FACTS}

The facts of White Resource Management are complicated. Those relevant to the discussion in this case comment are as follows:

\section{A. STATE OF THE REGISTER}

The following cavcats appeared on the certificate of title to the land in question in the following order:

- Caveat by A (Haida Resources Ltd.) protecting a mineral lease from the registered owner. ${ }^{3}$

Director Emeritus, Alberta Law Reform Institutc and Counsel, Reynolds Mirth Richards \& \&armer. The author is indebted to E. Mirth Q.C. for comments on an carlier draft of this note and for some of the content of the nute.

1 [1993] I W.W.R. 752. The Court delivered reasons for refusing leave (o) rearguc the appeal dated January 29. 1993. It is understerod that leave (1) appeal to the Supreme Court of Canada is being sought.

$=\quad$ R.S.A. 1980 c. L.-5.

3 The original holder of the lease was Pawnee Petrolcums Lid.. and therc were intervicwing assignments. hut nothing turned on this. 
- Caveat by B (White Resource Management) protecting a conflicting mineral lease from one Vold, a purchaser of the land under agreement for sale.

- Caveat by $\mathrm{C}$ (Durish) protecting an assignment of the Haida mineral lease from Haida.

\section{B. VOLD'S INTEREST}

Vold had an interest under an agreement for sale from the registered owner that was prior in time to the Haida lease. He had registered a caveat, but it had lapsed because he did not take proceedings to establish his interest when he was served with a notice under section 137 of the Land Titles Act. The lapse occurred after the registration of Haida's caveat, but before the registration of White's and Durish's caveats, that is, Vold's caveat was for a time on the certificate of title in priority to Haida's caveat.

\section{VOLD'S ASSIGNMENT TO C (DURISH)}

Later, Vold assigned to Durish his interest in the minerals, subject to White's lease, and then transferred title to Durish pursuant to the assignment. This assignment and transfer are not relevant to the principal questions in White Resource Management, but they made an unexpected appearance in the Court of Appeal's judgment in connection with the abuse-of-process point that will be discussed later.

\section{CLAIMS}

Durish claimed priority over White through the Haida lease and Haida's prior caveat. White claimed priority over Durish through its own caveat and Vold's agreement for sale.

Mr. Justice Mason, the trial judge, held that

- Vold's interest continued to have priority over the Haida lease despite the lapse of Vold's caveat.

- White's interest became entitled to Vold's priority over Haida and retained that priority after Durish acquired and caveated his assignment of the Haida lease.

\section{SECTION 195 OF THE LAND TITLES ACT}

The first question that arises trom the Court of Appeal's judgment is whether or not a purchaser of a caveated interest is entitled to the protection of section 195 of the Land Titles Act. The section reads as follows:

195 Except in the case of fraud. no person contructing or dealing with or taking or proposing to take a transfer, morgage, encumbrance or lease from the owner of any land in whose name a certificate of title has been granted shall be bound or concerned to inquire into or ascertain the circumstances in or the consideration for which the owner or any previous owner of the land is or was registered or to see to the 
application of the purchase money or of any part thereof, nor is he affected by notice direct. implied or constructive. of any trust or unregistered interest in the land, any rule of law or equity to the contrary notwithstanding. and the knowledge that any trust or unregistered interest is in existence shall not of itself be imputed as fraud.

Durish contracted with Haida. Haida was a caveator. The trial judge held that section 195 did not protect Durish because Haida was not a registered owner in whose name a certificate of title had been granted.

But the Court of Appeal said that it hesitated to agree with the trial judge that the section did not apply. Essentially, its reasons for hesitation were based on convenience rather than legal interpretation or doctrine: the ability to rely on the register, the court said, is the heart of the Torrens system, and Albertans and their lawyers have relied on section 195 in dealings with registered interests less than ownership. The court specifically referred to the use of agreements for sale protected only by caveat as an example of that reliance. It concluded that whether section 195 applies in favour of a person who deals with the holder of a registered or caveated interest "is an issue best resolved by statute, and is a fit subject of inquiry by the Alberta Law Reform Institute".' It assumed for the purposes of its judgment that section 195 did protect Durish, but it did not decide whether or not that assumption was correct.

Does section 195 apply to a purchase of a caveated interest? The wording of the section is doubtful. If compelled to decide the question, a court might take a robust approach to the interpretation of the Land Titles Act, as the courts have done in other cases." But, while the Court of Appeal obviously thought section 195 should apply to a purchase of any registered or caveated interest. it is not clear whether it thought that the section could apply. The answer to the question will remain in doubt until the courts decide it authoritatively or until legislation clarifies the section. The doubt extends not only to the purchase of a caveated interest but also to the purchase of a registered interest for which no certificate of title has been granted. e.g.. a purchase of a registered mortgage or lease.

If section 195 does not protect a purchaser, the notice and fraud rules of equity must apply. Those rules confer on a prior equitable interest priority over a subsequent interest unless the purchaser of the subsequent interest is a bona fide purchaser for value without notice of the prior interest. They fix the subsequent purchaser with constructive notice of

4. Mr. Justice W.E. Wilson has noted in an unpublished paper that s. 135 of the Lomd Tislex Act. S.A. 1906 c. 24. which was the Alberta prototype of $\mathrm{s}$. 195, applied to dealings with and dispositions from "the owner of any land for which a certificate of title has been granted". His research has showed that the change to the present version was made in the 1922 revision of the statutes. The change, being unexplained, was presumably made as part of the revision process, but it made it much more difficult to apply the section to dealings with a caveated owner.

s Supra note 1 at 757. The Institute undenook the inquiry. It has issued its Repon 63 which recommends amendments to $\mathrm{s}$. 195 to make it clear that the section applics to dealings with caveated and registered interests.

b. E.g., by recognizing equitable interests in the farte of $s .56$ which says that an instrument does not pass an estate or interest until registered. 
any conflicting interest that would have been discovered by a diligent investigation. They fix a purchaser who has actual or constructive notice with equitable fraud against the owner of the prior equitablc interest.?

Section 195 reverses these rules of equity. It abolishes the rules of constructive notice. It provides that a purchaser who is entitled to its protection is not affected by notice of off-register interests unless the purchaser has in fact participated in a fraud.

Other sections of the Land Titles Act confer priority on all registered and caveated interests according to time of caveating and registration. But section 195 is an important part of the protection conferred on purchasers by the Land Titles Act. If it does not apply, the holder of an off-register prior interest may try to use a purchaser's actual or constructive notice of the interest to obtain priority and thus make an end run around the priority rules of the Land Titles Act.

Where does that leave conveyancers who act for purchasers of interests for which no certificate of title has been granted? The answer is: in a considerable state of uncertainty. That uncertainty suggests that it would be prudent for conveyancers to make more inquiries about possible off-register interests than has been the practice, so as to avoid the consequences of the rules of constructive notice. It also suggests that it would be prudent for conveyancers to take steps to ensure that any off-register interests of which purchasers have notice are extinguished or subordinated to the interest being purchased.

\section{EFFECT OF LAPSE OR DISCHARGE OF CAVEAT ON THE EXISTENCE AND ENFORCEABILITY OF THE CAVEATED INTEREST}

The next question is whether an interest continues to be enforceable after the lapse or discharge of a caveat registered to protect the interest.

In White Resource Management, Vold registered a caveat to protect his interest under his agreement for sale from the owner of the land. But he did not take proceedings to substantiate his interest when served with a notice under section 137 of the Land Tilles Act. His caveat was therefore "lapsed by the Registrar". "What effect did the lapse of the caveat have on the existence, priority and enforceability of his interest? The authorities are in disarray. It is necessary to make an historical review of some of them. These are as follows: 


\section{A. UNION BANK OF CANADA v. BOULTER WAUGH LTD."}

The Union Bank was the holder of a registered mortgage. A prior caveat protected a security interest beneficially held by Boulter Waugh. The caveat lapsed under the Saskatchewan counterpart of Alberta's section 137. The Supreme Court of Canada held that Boulter Waugh's interest could not be enforced with priority over the bank's mortgage. This is the leading case for whatever it decided, but it has led appellate judges in different directions.

\section{B. BENSETTE v. REECE}

Reece was the registered owner of land. Bensette's prior caveat protected a royalty interest. The caveat lapsed under the same Saskatchewan provision. The notice to take proceedings was served by mail at the address for service in the land registry records and did not come to the attention of the caveators. The Saskatchewan Court of Appeal held that the caveators were entitled to priority over Reece. It did so essentially on the grounds that the caveated interest had attached to the fee simple estate when it was registered in Reece's name, and that the fee simple estate was not improved or enhanced by the removal of the caveat.

The members of the majority of the court dealt with Boulter Waugh as follows:

(a) Woods J.A. (who, with Hall J.A. constituted the majority of the court) distinguished it on the grounds that the contest in Boulter Waugh was between two encumbrances, while the contest in Bensette was between the registered owner of the fee simple and the owner of a royalty interest. It is not clear why different priority rules should apply between different sets of conflicting interests.

(b) Hall J.A. said that Boulter Waugh relied on doctrines of notice, to which the Saskatchewan counterpart of section 195 of the Alberta Land Titles Act was a complete answer, and that the Supreme Court therefore did not deal with the sections dealing with caveats. This is not easy to reconcile with the passages from Boulter Waugh that are quoted below.

\section{MCFARLAND v. HAUSER AND SUNDERLAND"}

McFarland registered a caveat. Then Sunderland registered a caveat. Sunderland served McFarland with a notice to take proceedings. McFarland commenced action but omitted to file a lis pendens, and his caveat lapsed. The following passages from the Appellate Division's reasons for judgment are pertinent: 
(a) Morrow J.A. (Moir J.A. concurring) said at page 352:

It follows from the above that the Sunderland caveat is properly filed. It follows that the McFarland caveat ... has no effect because it was allowed to lapse ...

And at pages $353-54$, he said:

As in the present case. in the case referred (o above [Bowher Waugh| the unsuccessful party had filed a caveat earlicr in time but under notice had allowed it to lapsc. thus allowing the sccond caveat to emerge as first in time on the tille. In holding that the old rules of equity as in noticc have been done away with and that the stute of the title as shown on the register has under the statute become the sole test, the learned Chief Justice went on to say ...

and quoted part of the passage of Davies C.J.'s judgment that is quoted below.

(b) McGillivray C.J. said at page 316:

The decisions seem uniform and clear. and they are that one who registers acquires a priority over unregistcred interests of which he had notice: see Boulter Waugh v. Union Bank of Can.. ...

McGillivray C.J.'s remarks were in the context of a situation in which the prior caveat had lapsed. Morrow J.A. specifically referred to the lapse. Therefore the majority of the Appellate Division held that Boulter Waugh means that the lapse of a prior caveat confers priority upon an interest protected by a caveat which, until the lapse, was subsequent to the prior caveat.

There was another ground for the majority judgment in McFarland. It was that the right of first refusal that was protected by McFarland's caveat was not an interest in land. The lapse-of-caveat point was, however, an alternative ground of decision. The Supreme Court of Canada reversed the Appellate Division on yet another ground, namely, that a provision in Sunderland's option made the option subject to McFarland's right of first refusal. It did not reverse the Appellate Division on the lapse-of-caveat point or otherwise deal with the point.

\section{PASSBURG PETROLEUMS LTD. v. LANDSTROM DEV. LTD.'}

Landstrom was the registered owner of land. It acquired its certificate of title subject to a prior caveat that had been registered by Quasar to protect a surface lease to Quasar from the previous registered owner of the land. Quasar assigned the lease to Passburg and then discharged its caveat. The Court of Appeal held that Passburg was entitled to enforce the assigned lease against Landstrom despite the discharge of Quasar's caveat. It did so on the grounds that Quasar's caveat had established privity of estate between Landstrom and the lease and that the discharge of the caveat did not affect the priority established by that privity of estate. Moir J.A., who gave the majority judgment, relied on Bensette 
and did not refer to Boulter Waugh or to the judgment of Morrow J.A. in McFarland, in which Moir J.A. himself had concurred and which appears contradictory.

\section{E. WHITE RESOURCE MANAGEMENT}

In White Resource Management, Vold's caveat lapsed while the Haida caveat was in force. Then Vold granted a petroleum and natural gas lease to White, who caveated, and Haida assigned to Durish, who caveated. The Court of Appeal held that Vold's interest survived the lapse of his caveat, and it affirmed Passburg. ${ }^{\text {13 }}$

The court gave the following rationale for Boulter Waugh: ${ }^{14}$

... at least the separate reasons of Mignault. J. (Cassells, J., ad hoc, concurring) and of Davies, C.J.. who together formed a majority, cmphasized that the remaining issue was about what loday we would call abuse of process. not a title issue. They refused relief to Boulter Waugh becausc it had no good reason for its carlier failure.

This outline of authorities shows that judges in the Alberta and Saskatchewan Courts of Appeal have interpreted Boulter Waugh in four different ways: (a) Boulter Waugh held that the lapse of a caveat deprives the caveated interest of priority: ${ }^{15}$ (b) Boulter Waugh applies only to a contest between encumbrances; ${ }^{16}$ (c) Boulter Waugh dealt only with questions of notice and not with the effects of the sections in the Land Titles Acts dealing with caveats: ${ }^{17}$ and (d) the Supreme Court refused relief to Boulter Waugh because it would be abuse of process to allow Boulter Waugh a second effort at enforcement when it had no good reason for its failure to bring action when called upon to do so. ${ }^{1 \mathrm{x}}$

Given this range of judicial interpretations of Boulter Waugh, we should look at what was said by the judges whose judgments were referred to in White Resource Management as authority for the abuse-of-process interpretation of the case.

\section{Davies C.J. said this: ${ }^{14}$}

I cannor find that the plaintilf has any one to blame but itscll for the position it finds itself in. The bank did not try to take any unjust advantage of it. Perfectly within its right. the bank took proceedings under the Act which resulted in the plaintiff being ordered 10 bring an action to cnforce that claim within a definite period, otherwise its caveal would lapse and be valcaled.

In its result. White Ressource Management subjected a purchascr. Durish. in a prior interest the protective caveat of which was not on the title at the time of the purchase. This goes beyond both Bensetle and Passbury. in which each owner had alcquired title subject to the caveat which subscquently lapsed. Such a result fows from the trial judge's reasoning, but it is accidental under the Court of Appeal's judgment. which. as will be seen. lumed on the presence of White's caveat. Supru note $I$ att $7(x)$.

is. McFurlemd v. Hatuser. supra note 11.

in Per Woods J.A. in Bensiselles. supret note 10.

17. Hall J.A. in Bensertle. strpra note 10.

in White Resontrol Mantrgement. supra note 1.

19. Supre note 1) at 38\%. Ilalics appear in the original. 
The respondent allowed it. by its own neglect and inaction, to be vacated and so lost the right it otherwise would have had to enforce its claim of priority ... I agree with Mr. Justice Newlands

that the lacating of the caveat cleared the registered tille to the land of any claim the plaintiff might hate against it in priority to any right that had antached to such land by. such lapice.

Mr. Justice Mignault said:"2

The learned Chicf Justice of Saskatchewan cites cerlain maxims coming. I think, originally from the Roman Law with which. as a civilian. I am familiar, such as nemo dat qui nom habet, or qui prior est tempore potior e'st jure. But I may say with deference that thesc maxims are not of universal application. and when third parties are concerned they cannot be applied without some qualification. It might, moreover, be possible to offset axiom by axiom and to reter to the one so often mentioned by the old jurists, vigilantibus nom domientibus scripta est lex. I prefer. however, to rest on the clear text of the staturc, and $\mathrm{J}$ take it as being eminently desirable, in the interest of the security of land transactions in a system where registration of tities to land is provided for, that the entries in the public register, in the absence of fraud, be taken as conclusive. Here the respondent failed to register its assignment and cven to protect its caveat when it was called upon in the manner prescribed for by "the Land Tirles Act" to do so. I cannut, under the circumstances of this cusc, come to its assistance.

There are references in these passages to Boulter Waugh's lack of activity. However, on my reading:

- what Davies C.J. said was that, as a matter of law, the vacating of Boulter Waugh's caveat took away Boulter Waugh's claim to priority.

- what Mignault J. said was that the clear text of the statute prevailed and that the entries in the register must be taken to be conclusive, that is, that the bank's caveat gave the bank's interest priority after the caveat protecting the Boulter Waugh interest lapsed.

I do not think that these passages say that the lapse of a caveat under the notice procedure leaves the priority of the caveated interest intact but subject, in the absence of a good reason for having allowed the caveat to lapse, to an abuse-of-process defence against the enforcement of the caveated interest.

But the Court of Appeal has spoken, and it has said that the question when an interest is asserted after the lapse of its protective caveat is one of abuse of process, not one of basic legal priority rights. Its interpretation of Boulter Waugh presumably prevails over that given in the older case of McFarland and is authoritative for Alberta. Presumably, either or both of the two Bensette interpretations are authoritative for Saskatchewan. These differing judicial interpretations suggest that the Supreme Court's judgment was unusually enigmatic. 
The Court of Appeal took the abuse of process point seriously in White Resource Management. It said that

... the Coun has the power to refuse to enforce the interest that the lapsed caveat had protected and that was subsequently assigned. We would exercise this power on the ground that it is an assignment of an interest that had, when challenged, not taken appmpriate steps for enforcement. The Court has the power to do so here notwithstanding the White caveat and the fact that it was on the title when Durish arrived.

Why then did the court enforce White's interest? Because Durish later took an assignment and transfer of Vold's interest from Vold and became registered as owner of the minerals. Having done so, Durish could not attack White's interest, which was derived from Vold. In its judgment the court said that it "invoked the rules of estoppel" against Durish. In its reasons for dismissing Durish's application to re-argue the appeal, the court put the point differently. The question whether White was guilty of abuse of process, it said, had been before it on the original appeal, and it had looked at all the circumstances, including Durish's behaviour. "This was not an application of the law of estoppel. In any event, even if the label is changed the result was inevitable."

The subsequent assignment and transfer from Vold to Durish made the facts of White Resource Management unusual, if not unique. Rarely will an interest that had been protected by a prior but lapsed caveat be acquired by the owner of a conflicting interest who is asserting priority for that conflicting interest over an interest derived from the interest that had been protected by the lapsed caveat. In more usual fact situations, a caveator will be unable, if the Court of Appeal's reasoning is applied, to enforce the interest after lapse of the caveat under notice, at least unless the caveator has a reason for not taking action when the lapsing notice is served that the courts will accept it as sufficient." But in the specific case under consideration by the court. the court enforced the interest. Perhaps it would be prudent to see what explanations the courts will accept as reasonable before drawing conclusions as to when enforcement will be permitted.

The Court of Appeal also said"2 that it would not permit the enforcement of an interest protected by a discharged (as differentiated from a lapsed) caveat if the discharge is given to settle a dispute and is expected to end the matter, or if the caveator must see that someone will take the discharge of the caveat as an abandonment of the interest (this latter statement applies to a lapse as well). Different considerations apply to discharges of caveats and this note will not deal with that subject.

Before leaving this part of White Resource Mancigement, one related point should be mentioned. The Court of Appeal said that an interest can be validly assigned after the lapse of its protective caveat only "if it is just in the circumstances to permit it".." The

The Court of Appeal (supra note I al 760) "would not wanl to be taken as adopting all the reasoning in Benselfe. The Cour there never asked itself whether Bensefle should be excused his failure (I) commence timely proceedings:". This leaves open the possibility that even the non-receipt of a lapsing notice (which occurred in Benserte) is not a sufficient reason for allowing the lapse to occur.

$=\quad$ lbid. at 759 .

2*. Ibid at 754 . 
court stated this proposition briefly at two points in its judgment. ${ }^{24}$ It did not give reasons for the proposition, and it did not say whether the "good reason" test would be applied to determine whether it is "just in the circumstances" to permit an assignment. It is not clear why the lapse of a protective caveat should prevent the owner of an interest from assigning whatever rights the owner has left after the lapse.

The principal lessons for conveyancers in this long discussion are as follows:

- the removal of a caveat under the lapsing procedure clears the caveat from the register but does not necessarily clear the interest from the owner's title. The underlying interest may still be there and it may be enforceable with priority over anything that was registered or caveated before the protective caveat lapsed.

- Alberta courts will not permit the owner of the previously caveated interest to enforce the interest unless they had a good reason for allowing the lapse to occur.

- it is uncertain what reasons for allowing a caveat to lapse Alberta courts will accept as good reasons.

- a purchaser or new mortgagee who relies on an invalid discharge of a caveat during the conveyancing process may find themself subject to the caveated interest. Even paying for a discharge may not be enough to get the benefit of it if the discharge is invalid. It may be good practice to ask for evidence that the interest that underlies the caveat has been extinguished, though even this, if the evidence proves false, will not provide complete protection. Other than that, if business is to get done, a conveyancer can only take whatever precautions are reasonable under the circumstances and hope for the best. ${ }^{25}$

\section{EFFECT OF CANCELLATION OF REGISTRATION OF AN INTEREST}

White Resource Management dealt with the effect of the lapse of a caveat on the then existing priorities of the caveated interest. It did not deal with the effect of the termination of a registration on the then existing priorities of the registered interest. However, if a registered interest can continue to exist after its registration is terminated, there is at least a risk that the Bensette, Passburg and White Resource Management reasoning would apply and that the interest will continue to maintain its existing priorities despite the termination of its registration.

It is not clear from the Lund Titles Act whether an interest can continue to exist after its registration is terminated. Sections 103(2) and 108(2) give some grounds for thinking that leasehold and mortgage interests terminate when their registrations terminate, but the wording is not ironclad. Sections $72(5)$ and 72.4, which provide for cancellation of registrations of utility rights of way, easements, restrictive covenants, party wall

:4. Mid. at 7.54. 761.

"This lesson has been there since Bense'lle' v. Reec's. suprat note 9. but has not generally been recognized. 
agreements and encroachment agreements, do not say anything about the effect of the cancellation of registrations.

The effect of the cancellation of the registration of a registered interest is therefore uncertain. It is uncertain whether the interest will remain in existence, whether it will remain enforceable, and whether it will remain enforceable with the priorities it had at the time of the cancellation.

\section{REASONS FOR PRIORITY OF WHITE'S INTEREST}

It is now time to examine the Court of Appeal's grounds for deciding that White's interest had priority over Durish's interest.

The court's grounds for decision are in the following passages:

1. Without more, the White caveat must defeat |Durish|. It was on the title when he acquired his interest. A caveat by Vold was not essential to the White claim. It could be advanced even if Vold never filed a caveat. A person who takes an assignment of an unregistered interest can, by registration of a caveat, protect that interest from claimants not yet on the title.

I distinguish this case from what the situation would be if, after the Vold caveat lapsed and before the White caveat were filed, a new interest was registered. In that event, the new interest could invoke s. 195 and claim that it relied on the prior existing certificate of title, and it did not then display any registered Vold interest. But that did not happen here. ${ }^{26}$

2. [The Vold interest] could be assigned, and the assignee could, as White did, protect that interest anew by a caveat. In that event, all future interests, including Durish, take subject to the caveated interest. ${ }^{27}$

3. But I suggest with respect that the law is now settled, at least for Alberta, that the indefeasibility rule protects only new interests who rely on the display of interests on the certificate of title at the time when the new interest was created. ${ }^{28}$

4. When Durish took the latest Pawnee assignment, his was a new interest and able to rely on the then-current state of the title. The trouble for

Supra note I at 757. In its dismissal of Durish's applicution for leave to re-argue. the court rejected his argument based on the state of the title "because he in fact did see on that day a registered competing interest, as disclosed by the White caveat. He did not rely on the prior existing certificate of title, he claimed rather that he could safely ignore what it disclosed".

27. Ibid. at 758. Vold did not assign his interest to White. Rather, he granted a mineral lease to White. The difference is immaterial. 
him remains, of course, that the White caveat, if not the Vold caveat. was therc to be seen when he acquired his interest. ${ }^{29}$

The reasoning in these passages is simple enough. White caveated first. Durish caveated second. Therefore White was entitled to priority. That is plain, ordinary Alberta land registration law.

But there is a hidden difficulty. White's caveat was not the first caveat on the register. Haida's caveat was first, and Haida assigned its rights to Durish. ${ }^{30}$

But the Court of Appeal, though it was aware of the existence of the Haida caveat, ${ }^{31}$ did not refer to it in giving its grounds for decision. On the face of it, this means that, in the court's view, the Haida caveat was so clearly irrelevant that it need not be referred to.

Why was the Haida caveat irrelevant? The passages quoted above suggest that it was irrelevant because Durish had a "new interest", one that was uncoupled from the interest protected by the Haida caveat and depended for its priority entirely on Durish's caveat. ${ }^{32}$

If this interpretation of the Court of Appeal's judgment is correct, the court meant to hold, and did hold, that an assignee is not entitled to the priority established by their assignor's caveat. If that is so, a prospective assignee who finds on the register a caveat or a registration after the prospective assignor's caveat takes the assigned interest subject to the interest protected by the intervening caveat or registration. ${ }^{33}$

The value of almost any interest in land depends upon its marketability. But if a subsequent caveat can prevent the owner of a prior caveated interest from passing on the priority established by the first caveat, the marketability of caveated interests will be seriously affected. The subsequent caveat might protect a prior off-register interest (which is White Resource Management, as the court treated White's caveat as protecting Vold's interest) or it might protect a subsequent interest (because White Resource Management says that an assignee's interest is a new interest dependent on its own caveat for priority). Depriving assignees of the benefit of their assignors' caveats would derogate seriously from the usefulness of caveats and from the facility of transfer that the land titles system is intended to promote.

Ibid. at 758.

Sce the judgment of Mason J.. supra note 2 at 135. 1.36.

Supra note 1 at 762.

The court said in the second passage quoted above that (the Vold interest/ could be assigned, and the assignee could, as White did, protect that interest anew by a caveat". (Emphasis added.) The court appears to have thought of the interest "assigned" to White as the same interest as that which was assigned. while it thought of the interest assigned to Durish as a new interest.

Note that s. 135.1 of the Land Titles Act, which is discussed in the next section of this comment, may provide a solution to some of the problems outlined in this section. 
Did the Court of Appeal intend to hold that an assignee is not entitled to the priority established by their assignor's caveat? If it did, it overruled the court's decisions in Calford v. Zellers (Western) ${ }^{34}$ and Demers v. Fountain Tire Distributors: ${ }^{35}$

- in Calford, the court held that an assignee was entitled to the priority established by their assignor's caveat. Instead of treating the assignee's interest as a new interest, Allen J.A., speaking for the majority, said:

The rights and interests created by the lease in favour of the lessee were still unchanged: only the holder of the lessee"s estate and intcrest had been changed."

- in Demers, the court also held that an assignee was entitled to the priority established by their assignor's caveat. Allen J.A., speaking for the court, said:

Here it should be noted that on the authority of the judgment of this Court in Calford..., it would appear that the filing of a caveat by Mrs. Demers was probably unnecessary to protect her interest as she could rely on the protection afforded by the caveal filed by Demers Transport. from which she acquired by assignment her interest in the propeny."

It seems unlikely that the court intended to overrule its previous decisions without mentioning them. Is there any other possible explanation of its apparent view that the Haida caveat was irrelevant?

One such possible explanation is the reasoning of Mr. Justice Mason, the trial judge in White Resource Management. This involved three steps. First, Vold's interest had privity-of-estate priority over Haida's lease despite the lapse of Vold's caveat. Second, Vold's lease to White carried with it Vold's privity-of-estate priority over Haida's lease. Third, the Vold's privity-of-estate priority followed the Haida interest through into Durish's hands. On this view, the Haida caveat and the "display of interests" of which it formed a part were immaterial. So was the White caveat; the trial judge's reasoning would have applied even if White had not caveated its interest. This reasoning, if accepted, gives valid grounds for holding that the priority of the Haida caveat was not decisive. By burdening Durish with the priority of Vold's off-register interest, it raises difficult and controversial questions of policy and intepretation, but that is another matter.

But the Court of Appeal did not accept the trial judge's reasoning. Instead, it based its decision entirely upon the priority of registration of White's caveat over Durish's caveat; if White's caveat had not been there when Durish acquired his interest. Durish would have won. ${ }^{38}$ The trial judge's reasoning therefore cannot be looked to as an explanation of the Court of Appeal's decision.

[1972] 5 W.W.R. 714 (App. Div.).

[1974] I W.W.R. 348 (App. Div.). In Passburg, the ussignee also got the benefit of their assignor's caveat. but it did so through the application of the privity-of-estatc doctrine.

Supra note 34 at 723.

Supra note 35 at 351 .

Supra note 1 at 757. 
As I have said, it does not seem likely that the court intended to upset its previous decisions that held that $\mathrm{C}$, an assignee, is entitled to the priority over $\mathrm{B}$ established by the caveat of A, C's assignor. However, the fact is that the court did not, in White Resource Management, give C's interest that priority. Its decision could be read in the light of other facts in the case, but the difficulty is that the court tied its decision to the relationship between caveats $B$ and $C$ and did not refer to the other facts or explain why A's caveat was irrelevant.

Conveyancers must, I think, take note of the fact that the Court of Appeal, when considering the relative priorities of caveats B (White Resource Management) and C (Durish), did not take into account the caveat registered by $A, C$ 's assignor. They should note that caveats and registrations intervening between caveats $A$ and $C$ may affect $C$ 's priority. They should also, I think, note the effect of the decision, until it is explained, on the marketability of caveated interests.

There may, however, be help in section 135.1 of the Land Titles Act, to which I now turn.

\section{EFFECT OF SECTION 135.1}

Section 135.1 of the Land Titles Act is as follows:

135.1(1) A caveat may be transferred by a caveator, or by his attorney or agent where the caveal is signed by the altorney or agent, and on registration of a transfer of the caveat the transferee has the samc priority as if he were the original caveator.

(2) On registration of a transfer of caveat the transferee becomes entilled to all rights granted by this Act to the caveator and subject to all liabilities imposed by this Act on the caveator.

(3) A transfer of caveat shall specify an address al which notices and proceedings relating to the cavcat or the subject matter of the caveat may be served.

The section was enacted after the facts of White Resource Management occurred, so that the caveat-transfer mechanism was not available in that case.

The section provides for the transfer of a caveat. But the caveat is not the caveated interest: it is merely the legal embodiment of, and protection for, the priority of the caveated interest. But the transfer of priority without a transfer of the interest to which the priority relates is an absurd concept. The section must necessarily assume that a caveat will never be transferred except as an incident of the transfer of the caveated interest.

Suppose that section 135.1 had been available in White Resource Management and that Haida had transferred its caveat to Durish when it assigned the mineral lease. The Court of Appeal, as has been noted, proceeded as if the Haida caveat was entirely irrelevant and characterized the assigned Haida lease in Durish's hands as a "new interest". Would a section 135.1 transfer of the Haida caveat have made the caveat relevant? I think it would. 
Otherwise section 135.1 is without meaning. But there was no transfer of the caveat and the court did not address the question.

But a purchaser may not be able to rely entirely upon a section 135.1 transfer of caveat for priority. The section may put a transferee entirely into the transferor/caveator's shoes. In White Resource Management, for example, Bensette and Passburg suggest that Haida's caveated interest was subordinated to Vold's off-register interest, so that if a section 135.1 transfer of caveat gave Durish "the same priority" as Haida, it would have left him subordinated to Vold's interest. The section could also be interpreted as subjecting the transferee to prior off-register equities created by the caveator such as a prior transfer of the caveated interest granted by the caveator.

Certainly, however. a conveyancer who takes an assignment or transfer of a caveated interest should take a transfer of the caveat under section 135.1. It is likely, though not certain, at least until the section is judicially interpreted, that a transfer of a caveat will confer on the transferee at lcast the priority enjoyed by the transferor.

\section{ACQUIRING A REGISTERED INTEREST}

In White Resource Management, Durish acquired an assignment of Haida's caveated interest and registered his own caveat, with White's caveat intervening. Suppose for the moment that Haida had had a registered interest and Durish had acquired and registered a transfer of that interest. On this hypothesis, would Durish have had priority?

Registration brings into play some additional sections of the Land Titles Act. Section 56 provides that an instrument, when registered, conveys the interest it purports to convey. This is not helpful in our hypothetical case, as it does not deal with priorities. Section 120 provides that a registered bona fide purchaser of an interest is not to be deprived of the interest on the grounds that the transferor or mortgagor was registered through fraud or error. Like section 56 , it does not deal with priorities. Section 57 provides that instruments rank in priority according to registration and not according to date. It does deal with priorities.

But the essence of Bensette. Passburg and White Resource Management is that a caveated interest continues to have its existing priorities despite the lapse of the caveat. In Bensette and Passburg, the previously caveated interest continued to have priority over the fee simple owner. It seems that Vold's previously caveated interest would continue to have priority over the Haida registered interest that I have hypothesized. If nothing had intervened, the hypothetical transfer to Durish of the hypothetical Haida registered interest would have been registered at a time when Vold's interest was not registered or caveated and should therefore rank in priority to the instrument which conferred Vold's interest. But White's caveat intervened. That would make it unsafe for a purchaser of the hypothetical Haida registered interest to rely on getting priority by registering a transfer of the registered interest. The intervening caveat might be based upon an interest that. through a lapsed or discharged caveat, had obtained priority over the registered interest. 
Again, the abuse-of-process doctrine enunciated by the Court of Appeal in White Resource Management may protect the purchaser of a registered interest against the assertion of rights based on an off-register interest previously protected by a caveat that has lapsed. But it would be unsafe to rely for priority on the inability of the owner of an interest that had been protected by a lapsed caveat that had lapsed to provide a satisfactory explanation.

\section{SECTION 62 OF THE LAND TITLES ACT}

Before leaving White Resource Management I should refer to one disturbing passage in it. It is as follows:"

I accept that. unlike in Passhurg. there probably is no privity between White and Durish. I qualify that denial because Durish did, afterwards, become registered owner on a iransfer from Vold. Like Landstrum in the Passburg case," Durish as a transferce covenants by statute to perform all the obligations of the Iransferor. See s. 62 of the Lund Tilles Act. As between Vold and White. Vold was obliged to honour his covenants to White in the assignment instrument. Durish, apart altogether from the White caveat, might be obliged to pertorm that obligation, particularly because he was well aware of it when he took title. But I do not rely on this argument.

This passage seems to suggest that under section 62 of the Land Titles Act a purchaser might be obliged to perform the covenants of a registered owner to the owner of a mineral lease interest that is neither caveated or registered (as the proposition stated by the court applies "apart altogether from the White caveat"). The passage is at most obiter dictum. It may not be more than mere speculation, as the court merely said that Durish might be obliged to perform Vold's covenants to White. But it should be examined further.

Section $62(1)$ is the relevant part of section 62 :

62(1) In every instrument transferring land for which a certificate of title has been granted. subject to mortgage or encumbrance, there shall be implied the following covenant by the transferee both with the transferor and the mongagee: That the transferee will pay the principal moncy, intercst, annuity or rent charge secured by the mortgage or encumbrance, after the rate and at the time specified in the instrument creating it, and will indemnify and keep harmless the transferor from and against the principal sum or other money secured by the instrument and from and against the liability in respect of any of the covenants therein contained or under this Act implied on the part of the transferor.

"Encumbrance" is defined by section $l(f)$ as

any charge un land created or effected for any purpose whatever, inclusive of morgage. mechanics" or builders' liens. when authorized by statute and executions against land. unless expressly distinguished.

4). The Passhury decision, supra nole 12, was based on privity of estate created hy the existence of Quasar's civeat on landstrom 's certificate of title and did not reter to s. 62. 
While the last words of section 62(1) refer to "any of the covenants" of the transferor "therein", the section applies only to land that is subject to a mortgage or encumbrance, that is, land that is security for a money claim. Then, the implied covenant is "both with the transferor and the mortgagee" and is therefore dependent upon the involvement of a mortgagee. On the face of it, the section does not apply to anything but security interests, and even there, according to authority, it is restricted to cases in which equity would imply an indemnification by the transferee in favour of the transferor. The Court of Appeal said in Guaranty Trust Company of Canada v. Bailey: ${ }^{41}$

Section 62(1), if applicable. contains one covenant which the transferee has with two parties, the transferor and mortgagec.

It is well settled that s. 62(1), Lund Tilles Act, represents a codification of the covenant formerly implied by the cours of equity which stated that a purchaser of encumbered property must protect his vendor from the encumbrance.

\section{And as it said in AMIC Mortgage Investment Corporation v. Abacus Cities Lid.:42}

... a number of cases such as Re Macdonald, 21 Alta. L.R. 66 ... and Guaranty Trust Co. of Can. v. Bailey ... confine the broad words of s. 62 to those cases where there would have been some equitable obligation to indemnify apan from statute. In other words, those cases read s. 62 as merely giving a direct right of indemnity in situations where equity would give an indirect one.

It is of course risky to discount or ignore a pronouncement of the Court of Appeal. But the land titles system would be upset by a side wind if transferees were bound by covenants contained in all kinds of off-register instruments. It is unlikely that the court meant to upset the system in that way. The words of section $62(1)$ and the weight of authority in the Court of Appeal are to the contrary.

\section{CONCLUSIONS}

In summary, the following lessons can be drawn from White v. Durish:

1. The lapse or discharge of a caveat does not of itself extinguish the underlying interest and may not affect the priority of the interest.

2. It may be good practice for a purchaser who relies upon the clearing of title by the lapse or discharge of a caveat to require evidence that the underlying interest has been extinguished or is being extinguished by the current conveyancing transaction.

3. But if a discharge and any such evidence of lapse or extinguishment prove to be forged or unauthorized, the underlying interest will still exist and may continue to have priority. 
4. In the absence of a satisfactory reason, it is an abuse of process to try to enforce an interest after the lapse of its protective caveat. It may not, however, be safe to rely on this proposition until it becomes the grounds for decision of a case, and a purchaser cannot be sure whether a satisfactory reason exists in a particular case until the courts have adjudicated the question.

5. Until the doubts about the scope of section 195 of the Land Titles Act are resolved, there is a risk that a purchaser of a registered interest (other than that of a registered certificate-of-title-holder) or of a caveated interest, will be subject to unregistered and uncaveated interests of which the purchaser has actual or constructive notice.

6. A caveat that is subsequent to a registered or caveated interest may claim an interest that has priority over a prior registered or first caveated interest. Every such subsequent caveat should therefore be examined carefully to see whether the interest claimed could be, or could be derived from, an interest that was previously registered or caveated in priority to what is now the first caveated interest. A counsel of perfection might be to search discharged interests back to the time when the register was clear in order to see whether interests that were protected by lapsed or discharged caveats could have continuing priority.

7. The taking of a transfer of a caveat under section 135.1 of the Land Titles Act is likely to give the transferee at least the priority enjoyed by the transferor and is therefore a useful precaution, but it may not protect the transferee against off-register interests that have priority over the transferor, including equities created by the transferor.

It has, of course, always been true that the purchascr of a caveated interest is dependent upon the existence and validity of the interest under the general law. The caveating of an interest gives no guarantee that the interest is valid.

These lessons are derived from the present Land Titles Act and its judicial interpretation. The Alberta Law Reform Institute expects to issue a report that will recommend the adoption for Alberta of the Model Land Recording and Registration Act proposed by the Joint Committee on Land Titles. That Act addresses all the problems that are discussed in this comment. 